\title{
Mikroenkapsülasyon Sisteminin Aljinat-Hücre Süspansiyon Yoğunluğuna Bağlı Hızlarının Değerlendirilmesi
}

Evaluation of Alginate-Cell Suspension Density by Microencapsulation System's Flow Rate

\author{
Ömer Faruk Düzenli' ${ }^{1,2}$ (D) Beyza Göncü ${ }^{1,3}$ (D) Emrah Yücesan ${ }^{4}$ (D) Harika Salepçioğlu Kaya ${ }^{5}$ (D),
} Yeliz Emine Ersoy ${ }^{5}$ (D) Adem Akçakaya ${ }^{5}$ (i)

\footnotetext{
${ }^{1}$ Bezmialem Vakıf Üniversitesi, Deneysel Uygulama ve Araştırma Merkezi, İstanbul, Türkiye

2 İstanbul Üniversitesi, Sağlık Bilimleri Enstitüsü, İstanbul,Türkiye

${ }^{3}$ Bezmialem Vakıf Üniversitesi, Sağlık Hizmetleri Meslek Yüksekokulu, Tibbi Laboratuvar Teknikleri Programı, İstanbul,Türkiye

${ }^{4}$ Bezmialem Vakıf Üniversitesi, Tıp Fakültesi, Tibbi Biyoloji Anabilim Dalı, İstanbul,Türkiye

${ }^{5}$ Bezmialem Vakıf Üniversitesi, Tıp Fakültesi, Genel Cerrahi Anabilim Dalı, İstanbul,Türkiye
}

ORCID: Ö.F.D. 0000-0002-2938-711X;

B.G. 0000-0001-6026-8218;

E.Y. 0000-0003-4512-8764;

H.S.K. 0000-0001-8557-8140;

Y.E.E. 0000-0002-5028-6436;

A.A. 0000-0003-3116-7033

Sorumlu Yazar/Corresponding Author: Ömer Faruk Düzenli,

Bezmialem Vakıf Üniversitesi, Deneysel Uygulama ve Araştırma Merkezi, İstanbul, Türkiye E-posta: oduzenli@bezmialem.edu.tr / bgoncu@bezmialem.edu.tr

Geliș tarihi/Submitted: 03.03.2021 İlk revizyon/First Revision Received: 10.03.2021 Son Revizyon/Last Revision Received: 13.03.2021 Kabul Tarihi/Accepted: 06.05.2021

Atıf/Citation: Duzenli OF, Goncu B, Yucesan E, Salepcioglu Kaya H, Ersoy YE, Akcakaya A. Evaluation of alginate-cell suspension density by microencapsulation system's flow rate. Sağlik Bilimlerinde İleri Araştırmalar Dergisi 2021; 4(3) 87-94.

https://doi.org/10.26650/JARHS2021-928887
ÖZ

Amaç: Mikroenkapsülasyon tekniği sağlık bilimlerinde ilaç veya hücre gibi terapötik araçların bir kaplayıcı malzeme ile kaplanarak hem taşınımı hem de muhafazasını sağlamak amacıyla kullanılmaktadır. Kaplayıcı materyal olarak doğal olan ve olmayan birçok polimerik malzeme kullanılmaktadır. Bunlar arasında biyouyumluluğu ve yapısal stabilitesinden dolayı ultra saf aljinat avantajlı konumdadır. Bu çalışmada ultra saf aljinat ile paratiroit hücreleri kullanılarak mikroenkapsülasyon için ideal aljinat-hücre süspansiyon oranını, uygun hücre izolasyon metodunu ve mikroenkapsülasyon oluşturmak için kullanılan sistemin en uygun akış hızını belirlemek amaçlanmıştır.

Gereç ve Yöntem: Çalışmada dört ayrı paratiroit dokusundan, iki farklı izolasyonla (enzimatik/ mekanik) elde edilen paratiroit hücreleri kullanılmıştır. Hücreler serum fizyolojik ile süspanse hale getirilerek farklı miktarlarda aljinat ile enkapsüle edilmiștir. Sonrasında belirlenen aljinathücre süspansiyon oranları, iki farklı izolasyonla elde edilen paratiroit hücreleri ile farklı akış hızlarında enkapsüle edilerek in vitro olarak morfolojileri ve hücrelerin salgıladığı parathormon miktarı takip edilmiștir.

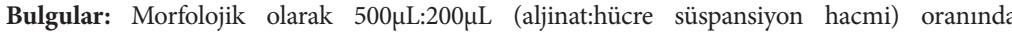
hazırlanan enkapsüllerin in vitro olarak verimli olduğu belirlenmiştir. Böylelikle $\% 28$ oranında aljinat-hücre süspansiyon oranı sabit tutularak; mekanik izolasyonlu hücrelerin kullanıldığı mikroenkapsüllerin morfoloji ve cihazın akış hızına negatif etki oluşturduğu belirlenmiştir Yalnızca enzimatik hücre izolasyonu yapılan paratiroit hücreleri farklı akıs hızlarında morfolojik farklılıklar oluşturmuş ve $2,5 \mathrm{~mL} /$ dakika hızın yapı, salgıladıkları parathormon ve stabilite açısından verimli oldukları belirlenmiştir.

Sonuç: Hücrelerin salgıladığı ürünlerin kapsül alanı dışına ulaşması hücremikroenkapsülasyonunun temel işleyişini oluşturmaktadır. Yapısal stabilitenin korunması, mikroenkapsüle edilen hücrelerin etkin şekilde beslenmesine olanak sağlamalıdır. Ayrıca bu çalışma ile aljinat-hücre süspansiyon oranı, uygun hücre izolasyon metodu ve akış hızı sınırları netleştirilmiştir. Gelecek çalışmalarla belirlenen değerlerin uzun in vitro takiplerinin yapılması gerekmektedir.

Anahtar Kelimeler: Paratiroit, Mikroenkapsülasyon, Aljinat, Ultrasaf-aljinat, Kapsülasyon

\section{ABSTRACT}

Objective: The microencapsulation technique is mainly used in health sciences to provide both transport and preservation of therapeutic tools, such as drugs or cells, by coating them with a coating material. Naturally occurring and synthetic (non-natural) polymers are widely used as a coating material. Unlike others, the ultrapure alginate is more advantageous due to its high biocompatibility and structural stability. In this study, our aim is to determine the ideal alginatecell suspension ratio for microencapsulation, the appropriate cell isolation method, and the optimum flow rate of the system by using ultra-pure alginate and parathyroid cells.

Materials and Methods: In this study, parathyroid cells were obtained from four different parathyroid tissues through two different isolation methods (enzymatic/mechanical). The cells were suspended in an isotonic saline solution and encapsulated with different amounts of ultrapure alginate. Afterward, the determined alginate-cell suspension ratio was microencapsulated with parathyroid cells, and different flow rates, morphology, and the amount of parathyroid hormone secretion were followed in vitro.

Results: Morphologically, the ratio of $500 \mu \mathrm{L}: 200 \mu \mathrm{L}$ (alginate:cell suspension volume) microencapsules was the most stable and efficient group in vitro. By this, the $28 \%$ alginate:cell suspension ratio was stabilized. The microencapsulated of the mechanically isolated cells were 
not found stable morphologically and negatively impacted the flow rate of the system. Particularly, enzymatic isolated parathyroid cells have high structural stability without showing equal distribution; however, only the $2.5 \mathrm{~mL} /$ minutes flow rate provided the equal distribution and stable parathormone release.

Conclusion: The basic principle of cell-microencapsulation is that the released products reach the outside of the capsule area. In addition, maintaining structural stability allows access to the nutrients to pass easily for the cells. In this study, the alginate-cell suspension ratio, favorable cell isolation method, and flow rate limits were clarified. An in vitro long-term, follow-up should be evaluated by future studies. Keywords: Parathyroid, Microencapsulation, Alginate, Ultrapure-alginate, Capsulation 


\section{GİRIŞ}

Bir malzemenin doğal veya doğal olmayan bir materyal ile mikro düzeyde kaplanması işlemi mikroenkapsülasyon olarak adlandırılır (1). Birçok endüstride uygulama alanları olmasının yanı sıra sağlık bilimlerinde de terapötik amaçlarla kullanılmaktadır $(1,2)$. Yarı geçirgen bir yapı ve yapısında kullanılacak materyale göre biyouyumluluk düzeyinin istenilen seviyede olmasını sağlamak, enkapsülasyon tekniğinin önemli avantajlarındandır. Ayrıca enkapsülasyon immün sistemi atlatmak için kullanılabilecek önemli tekniklerden biridir (3). Enkapsülasyon malzemesi kapsülün dışı ile içi arasında bir bariyer sağlayacağ için immün sistem hücreleri tarafından kapsül içerisindeki malzeme fark edilemeyip immün sistem yapıları tarafından yakalanamayacaktır (4). Böylelikle, tedavi seçenekleri açısından genellikle ilaç veya hücre nakli temelli uygulamalarda kullanılmaktadır (2).

Mikroenkapsülasyon için genellikle doğal polimerden aljinat, kitosan veya selüloz; doğal olmayan polimerden sodyum aljinat, kolajen veya polietilen glikol (PEG) gibi materyaller tercih edilmektedir (3). Aljinatı diğer materyallerden daha avantajlı kılan özellik, saflığı arttıkça biyouyumluluğu ve stabilitesinin de o paralelde artmasıdır. Özellikle, ultra saf aljinat, aljinatın bu anlamda birçok çalışmada tercih edilen önemli bir çeşididir. Ultra saf aljinat pankreas adacık hücre nakli $(5,6)$, in vivo olarak mezenkimal kök hücre nakli (7) ve paratiroit hücre nakli (8) gibi birçok klinik çalışmada kullanılmıştır.

$\mathrm{Bu}$ çalışmanın amacı; daha önce literatürde bildirilmemiş olduğundan, mikroenkapsülasyon oluşumu için uygun aljinat-hücre süspansiyonu oranını belirlemek ve etkin hücre izolasyon metodunun seçilmesiyle mikroenkapsülasyon sürecinin optimum akış hızı dengesinin araştırılmasıdır. Model organizma olarak paratiroit hücreleri tercih edilmiş ve kültürdeki fonksiyonel aktivitelerinin belirlenmesi için parathormon (PTH) miktarı belirlenmiştir.

\section{GEREÇ VE YÖNTEM}

Çalışma Bezmialem Vakıf Üniversitesi Girişimsel Olmayan Araştırmalar Etik Kurulu onayı ile gerçek- leştirildi (Kabul numarası: 54022451-050.05.04-522). Çalışma kapsamında kullanılan paratiroit dokuları için gönüllülerden onam formu alındı ve sonrasında deneysel süreç başlatıldı.

\section{Hücre İzolasyonu}

Çalışma kapsamında iki tip hücre izolasyon metodu kullanıldı. Mekanik ve enzimatik hücre izolasyonu aşamasında, Yücesan ve ark. tarafından uygulanan metotlar sirasiyla kullanıldı $(1,9)$. Elde edilen hücrelerin canlılık tayinleri Muse Hücre Analiz cihazı (Merck Millipore, Germany) ile belirlendi. Her izolasyon grubu için iki doku kullanıldı. Mikroenkapsülasyon aşaması için her grup kendi içinde havuz oluşturularak değerlendirildi.

\section{Mikroenkapsülasyon}

İlk aşama olarak; aljinat miktarına bağlı hücre-süspansiyon miktarının optimizasyonu yapıldı. Ultra saf aljinat maddesi (Pronova UP MVG; Nova Matrix, Oslo, Norway) \%2 oranında hazırlandı. Aljinat-hücre karışım oranını belirleyebilmek için 4 grup oluşturuldu. Gruplarda, \%2'lik ultra saf aljinat ile her bir grupta $10 \times 10^{6}$ hücre içeren, $200 \mu \mathrm{L}$ final hacimdeki hücre süspansiyonu sabit olacak şekilde değişken oranlarda aljinat ile karıştırıldı. Aljinat oranları; 200 $\mu \mathrm{L}, 300 \mu \mathrm{L}, 400 \mu \mathrm{L}$ ve $500 \mu \mathrm{L}$ olarak kullanıldı. Hücre-aljinat karışımları 15 gauge şırınga ucu ile 300 mOsm $\mathrm{CaCl}_{2}$ içeren çözeltiye manuel olarak (kapsülasyon cihazı kullanılmadan) yavaşça damlatıldı. Ortamdaki fazla kalsiyum, kapsüllerin izotonik su çözeltisi ile yıkanmasıyla uzaklaştırıldı. Ardından kapsüller $37^{\circ} \mathrm{C}^{\prime} \mathrm{de} \% 5 \mathrm{CO}_{2}$ içeren nemli inkübatörde kültüre edildi. Kültürün ardından, her bir gruptaki kapsüllerin morfolojileri kontrol edilerek takipleri yapildı.

İkinci aşama olarak kapsülasyon cihazında (Pump 11 Pico Plus Elite Infusion/Withdrawal Programmable Dual Syringe Pump, Harvard Apparatus ${ }^{\mathrm{m} x}$, Holliston, MA, USA) uygun aljinat-hücre süspansiyonu karışımına farklı akış hızlarında kapsül oluşumu uygulandı. Süreye bağlı hacim, akış hızı olarak ifade edilmiştir. Kapsülasyon cihazında dakikada $1 \mathrm{~mL}$, 1,2 mL, 1,5 mL, $2 \mathrm{~mL}$ ve 2,5 mL damlatma kapasitesiyle kapsüller oluşturuldu. Kapsül formasyonu için 
Doku \#1
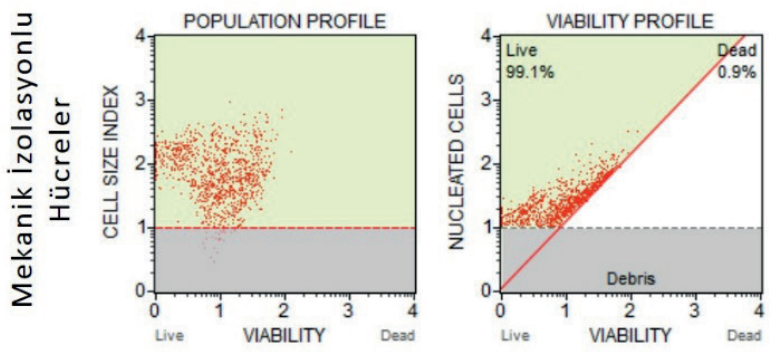

Doku \#3
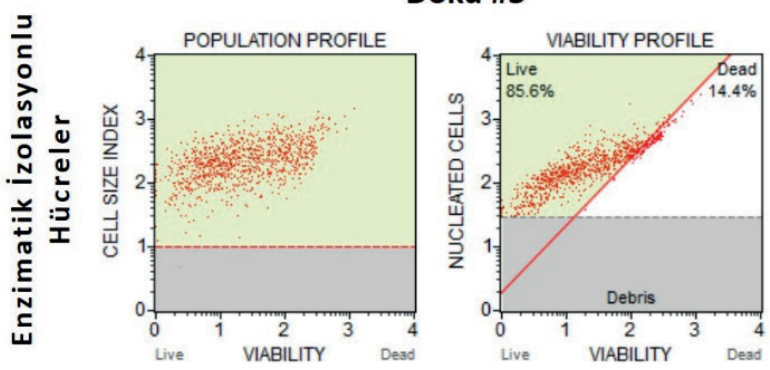

Doku \#2
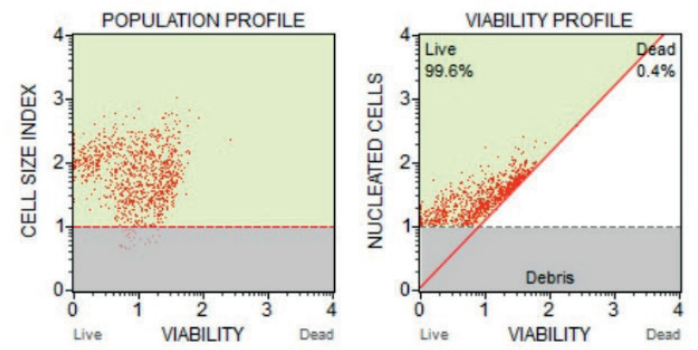

\section{Doku \#4}
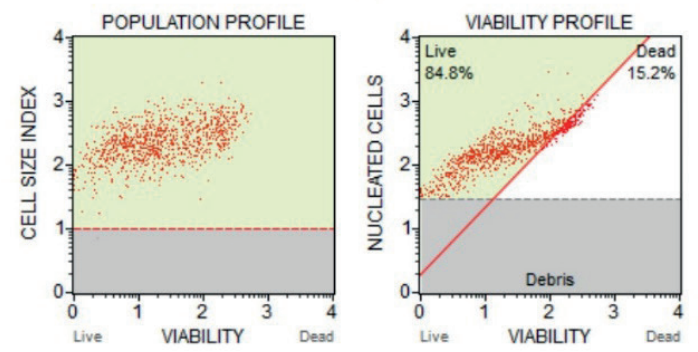

Şekil 1. Mikroenkapsülasyon aşamasında kullanılan paratiroit hücrelerinin akış sitometrisinde belirlenen popülasyon ve canlılık profilleri. Mekanik yollarla izole edilen hücrelerin popülasyon profilleri birbirlerine benzerdir (Doku\#1 ve Doku\#2). Enzimatik izolasyon yöntemiyle elde edilen hücrelerin popülasyon profilleri benzer dağılım göstermektedir (Doku\#3 ve Doku\#4).

$300 \mathrm{mOsm} \mathrm{CaCl}_{2}$ içeren çözelti kullanıldı. Elde edilen kapsüller izotonik su çözeltisi ile yıkandıktan sonra McCoy's (Gibco, Thermo, MA, USA) hücre kültür medyumu içerisinde kültüre edildi. 1. ve 7. günlerde PTH miktarını ölçmek için her grubun süpernatant1 toplanıp $-80^{\circ} \mathrm{C}$ 'de saklandı.

\section{PTH Seviyesinin Belirlenmesi}

İnsan PTH ELISA kit (RayBiotech Inc, Norcoss, GA, USA) kullanılarak kültürün 1. ve 7. gününe ait süpernatant örneklerindeki PTH miktarları belirlendi. Mark Microplate Absorbance Reader (Bio-Rad, USA) cihazında absorbans ölçümü (450 nm) gerçekleştirildi.

\section{İstatistiksel Değerlendirme}

Bulgular Graphpad (Prism v9.01) arayüzü kullanılarak değişkenler arası istatistiki anlamlılık t-test kullanılarak değerlendirildi. $\mathrm{p}<0,05$ anlamlılık sınırı olarak kabul edildi.

\section{BULGULAR}

Çalışmada 4 adet paratiroit dokusu kullanıldı. Bu dokulardan mekanik ve enzimatik yöntemler kullanılarak hücre izolasyonu gerçekleştirildi. Elde edilen hücre kültürlerine ait canlılık ve popülasyon profilleri tespit edildi. Canlılık oranları mekanik izolasyonlu hücreler için ortalama \%99,35 (Doku\#1 \%99,1 Doku\#2 \%99,6), enzimatik izolasyonlu hücreler için ortalama \%85,2 (Doku\#3 \%85,6 Doku\#4 \%84,8) olarak belirlenmiştir (Şekil 1). Çalışma süresince izole edilen mekanik ve enzimatik hücreler kendi grupları içinde havuz oluşturularak kullanılmıştır.

Kapsülasyon cihazının ideal akış hızını belirlemeden önce, kullanılacak aljinat-hücre süspansiyonu karışım oranı belirlendi. Bu optimizasyon sürecinde, $200 \mu \mathrm{L}, 300 \mu \mathrm{L}, 400 \mu \mathrm{L}$ ve $500 \mu \mathrm{L}$ aljinat miktarlarında sabit sayıda hücre $\left(10 \times 10^{6}\right.$ hücre) içeren ve sabit hacimde (200 $\mu \mathrm{L}$ final hacim olacak şekilde serum fizyolojik içerisinde) hücre süspansiyonu kullanılarak takip edildi. Bir haftalık morfolojik takibin sonunda yalnızca $500 \mu \mathrm{L}$ aljinat içeren grubun kapsüllerinde morfolojik stabilite gözlendi. Diğer oranlardaki aljinat/hücre süspansiyonu karışımlarının kullanıldığı kapsüllerde morfolojik açıdan çatlama ve yapının dağıldığı gözlemlendi. Çalışmanın buradaki sonuçlarına göre aljinat-hücre süspansiyonu oranı $\% 28$ olarak dengelenmesi, yapının stabil olması için uygun olduğu belirlendi. 


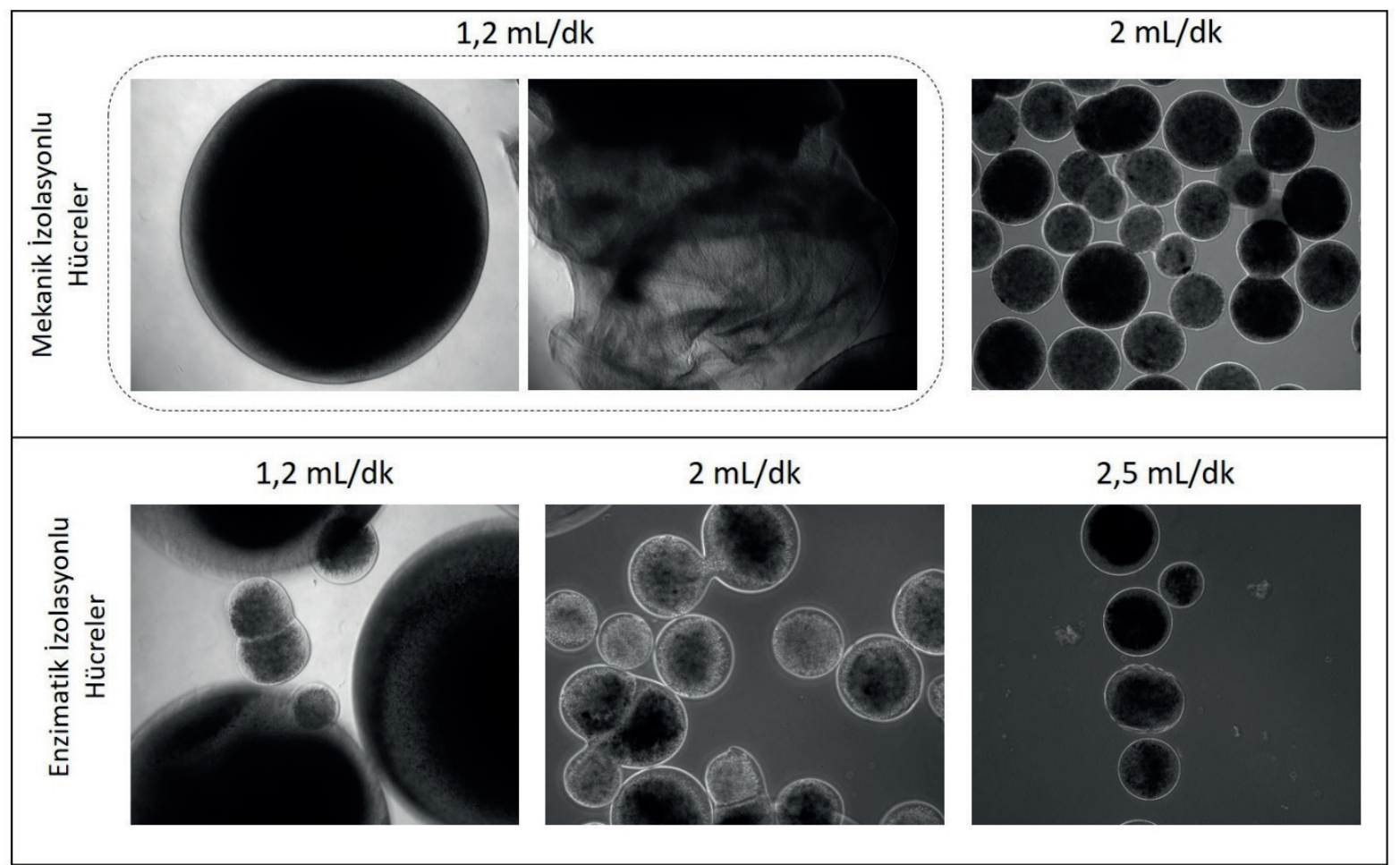

Şekil 2. Kapsülasyon cihazı kullanılarak farklı akış hızlarında oluşturulan mikroenkapsüle hücrelerin mikroskop görüntüleri. Üst panelde mikroenkapsüle edilmiş mekanik yollarla izole edilen paratiroit hücrelerinin kullanıldığ grup gösterilmektedir. Çizgili dörtgen içerisinde yer alan görsel; cihaz akış hızının 1,2 mL/dk uygulanmasıyla elde edilen kapsül formasyonu görülmektedir. Aynı alan içerisindeki sağ panelde ise akış hızına bağlı mekanik hücrelerin kapsül oluşumu gerçekleşememiş ve cihazın itiş kapasitesi negatif etkilenmiştir. Sağ panelde, cihaz akış hızının $2 \mathrm{~mL} / \mathrm{dk}$ olarak ayarlanması neticesinde ortaya çıkan mikroenkapsüller görülmektedir. Boyutlarının homojen oluşumu ve kapsüllerin bireysel olarak ayrılması sağlanamamıştır (büyütme oranı 4X). Alt panelde mikroenkapsüle edilmiş enzimatik izolasyon ile elde edilen paratiroit hücrelerinin kullanıldığı gruplar gösterilmiştir. Sol görselde, kapsüller 1,2 mL/dk akış hızı kullanılarak oluşturulmuştur. Kapsül boyutları kendi içinde farklılık göstermektedir. Orta kısımda yer alan görselde, akış hızı 2 mL/dk olarak kullanılmış ve bu kapsüller boyut olarak birbirine yakın olsalar da birçoğu birbirleriyle yapışık halde bulunmaktadır. Sağ görseldeki akış hızı 2,5 mL/dk olarak uygulanmış ve hem kapsül morfolojilerinin tekil olduğu hem de boyutlarının homojen dağıldığı görülmektedir (büyütme oranı $4 \mathrm{X})$.
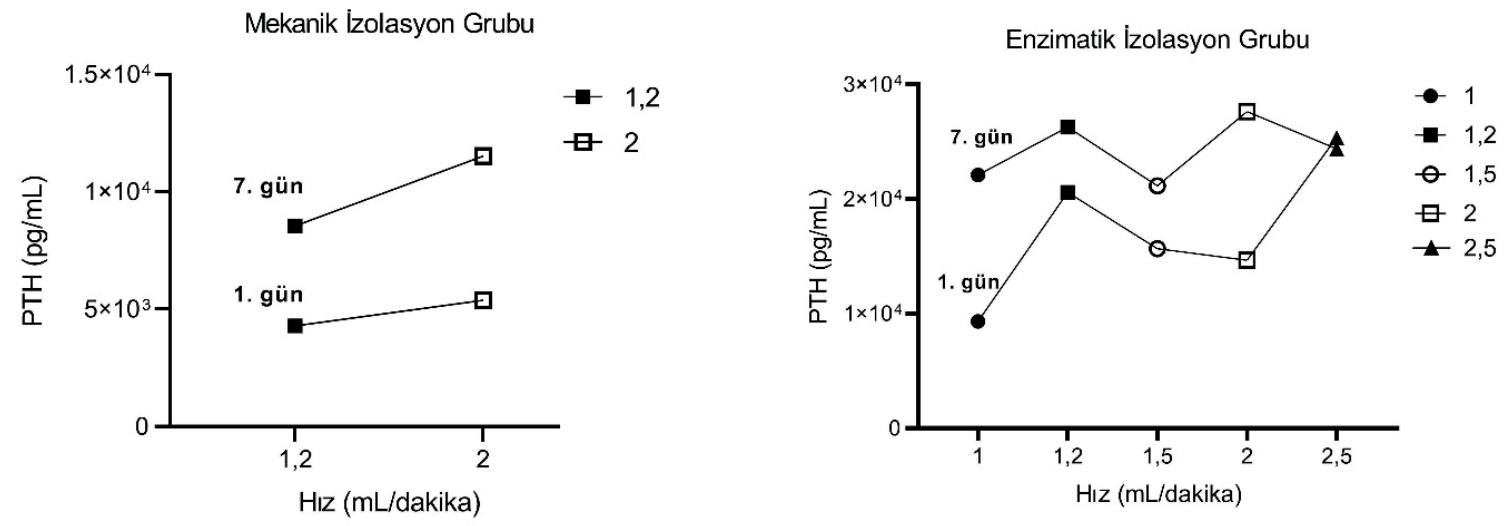

Şekil 3. Kapsülasyon cihazı kullanılarak farklı akış hızlarında mikroenkapsüle edilen paratiroit hücrelerinin in vitro takibi sonucu 1. ve 7. günlerde salgıladıkları PTH miktarları. Sırasıyla mekanik ve enzimatik izolasyonun kullanıldığı kapsül grubunun sonuçları. PTH:Parathormon. 
Tablo 1. Kültüre edilen mikroenkapsüllerin 1. ve 7. günlere ait PTH sonuçları.

\begin{tabular}{|c|c|c|c|c|}
\hline & & $\begin{array}{c}\mathrm{Hiz}(\mathrm{mL} / \\
\mathrm{dk})\end{array}$ & $\begin{array}{l}\text { 1. Gün } \\
\text { PTH }\end{array}$ & $\begin{array}{l}\text { 7. Gün } \\
\text { PTH }\end{array}$ \\
\hline \multirow{5}{*}{ 点 } & \multirow{5}{*}{ 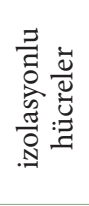 } & 1 & 9313 & 22096 \\
\hline & & 1,2 & 20579 & 26274 \\
\hline & & 1,5 & 15667 & 21156 \\
\hline & & 2 & 14653 & 27619 \\
\hline & & 2,5 & 25361 & 24374 \\
\hline \multirow{2}{*}{ 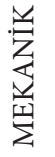 } & \multirow{2}{*}{ 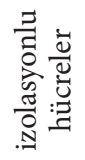 } & 1,2 & 4290 & 8539 \\
\hline & & 2 & 5376 & 11518 \\
\hline
\end{tabular}

PTH:Parathormon, pg/mL:pikogram/mililitre.

Tespit edilen ideal aljinat/hücre süspansiyonu oranı (\%28) kullanılarak kapsülasyon cihazında sırasıyla mekanik izolasyonlu hücrelerin kullanıldığı karışım dakikada $1,2 \mathrm{~mL}$ ve $2 \mathrm{~mL}$ ve enzimatik izolasyonlu hücrelerin kullanıldığı karışım dakikada $1 \mathrm{~mL}, 1,2$ mL, 1,5 mL, 2 mL ve 2,5 mL damlatılacak şekilde akış hızları değerlendirildi. Mikroenkapsülasyon oluşumu için divalent katyon olarak $\mathrm{CaCl}_{2}$ çözeltisine aljinat/ hücre karışımı damlatıldı. Akış hızına bağlı kapsül oluşum süreçleri Video l'de gösterilmiştir. Kapsüllerin morfolojileri ışık mikroskobu altında gözlemlendi (Şekil 2). Ardından, kapsüller kültüre edilerek 1. ve 7 . günlerde süpernatant örnekleri topland. Toplanan süpernatantlar kullanılarak kapsül içerisindeki hücrelerin salgıladığı PTH oranları belirlenerek (Tablo 1), günlere bağlı gruplar arası değişim Şekil 3’de gösterildi. Mekanik izolasyon grubunda örneklem sayısı azlığı nedeniyle istatistiksel analiz yapılamadı. Fakat, mekanik izolasyonlu hücreleri içeren kapsüllerin ürettiği PTH miktarı hem 1. günde hem de 7. günde enzimatik izolasyonlu gruplardan çok daha az miktarda olduğu gözlendi (Şekil 3). Enzimatik izolasyon grubu ölçümlerinde ise $1 \mathrm{~mL}, 1,2 \mathrm{~mL}, 1,5 \mathrm{~mL}$, $2 \mathrm{~mL}$ akış hızları zamana bağlı olarak, sabit kültür koşullarında anlamlı değişiklik gösterdi $(\mathrm{p}=0,0215)$ (Şekil 3). Yalnızca dakikada 2,5 mL akış hızına sahip grubun salgıladığı PTH zamana bağlı olarak stabil seyrettiği gözlendi.

\section{TARTIŞMA}

Mikroenkapsülasyon, biyouyumlu bir maddenin kullanımıyla özellikle hücre temelli veya hedeflendirilmiş ilaçların tedaviye yönelik kaplanmasıyla oluş-
Video 1. Mekanik ve enzimatik izolasyon ișlemi ile elde edilen paratiroit hücrelerinin kapsülasyon cihazı kullanılarak mikroenkapsüle edilmesi süreci. Mekanik izolasyonlu hücreler 1-24. saniyeleri arasında 1,2 mL/dk ve $2 \mathrm{~mL} / \mathrm{dk}$ akış hızıyla mikroenkapsülasyon gerçekleştiriliyor. Enzimatik izolasyonlu hücreler 28.saniye ve 1 .dakika arasında $1 \mathrm{~mL} / \mathrm{dk}, 1,5$ $\mathrm{mL} / \mathrm{dk}$ ve $2 \mathrm{~mL} / \mathrm{dk}$ akış hızıyla mikroenkapsülasyon uygulaniyor.

https://cdn.istanbul.edu.tr/file/JTA6CLJ8T5/A425FB33A5F84C779C573392A1DBA9A2

turulan taşıyıcı bir sistemin oluşturulmasıdır. $\mathrm{Bu}$ yolla özellikle hücre nakli hedef ise immün sistem etkilerinden de korunma sağlanabilmektedir (3). Literatürde; tip I diyabet (10-13), mezenkimal kök hücrelerin hedeflendirilmesi (14), kalıcı hipoparatiroidi tedavisi için paratiroit hücrelerinin kapsülasyonu $(8,15)$ ve deneysel olarak tiroit dokusunun kapsüle edilmesi (2) gibi çalışmalar bildirilmiştir.

Kalıcı hipoparatiroidi, tiroit operasyonları esnasinda kanlanması bozulan ve/veya istenmeden alınan paratiroit dokularının yokluğu sonucunda oluşan bir hastalıktır $(9,16)$. Türkiye'nin endemik bir guatr ülkesi olması, kalıcı hipoparatiroidi görülme sıklığını da aynı şekilde artırmaktadır (17). Kalıcı hipoparatiroidi için yaygın olarak semptomatik tedavi uygulanmakta ve hayat boyu ilaç kullanımını gerekmektedir. Hayat boyu ilaç kullanımının birçok yan etkisi bulunmaktadır. Hastaların semptomatik tedavileri uzadıkça, gözlenen yan etkilerin artışı hastane yatışı gereksinimlerini artırmaktadır. Bazı ağır seyreden kalıcı hipoparatiroidi semptomları hastaların uzun dönem intravenöz kalsiyum ihtiyacına neden olur $(1,9,18)$. Bu da hem hasta ve yakınları açısından s1kıntılı bir süreç olmakta hem de ülkenin sağlık ekonomisine yük getirmektedir. Klinik olarak uygulanmakta olan küratif tek tedavi seçeneği paratiroit naklidir. Paratiroit naklinin tarihteki ilk uygulaması 1911 yılında (19) yapılmıștır ve 1997 yılında ise ilk kapsüle paratiroit hücre nakli gerçekleştirildiği bildirilmiştir (20).

Günümüzde organ nakillerinde kullanılan immunsüpresif ilaçların kullanımı yan etkilerinin daha ağır olması sebebiyle kalıcı hipoparatiroidi hastaları için önerilmemektedir $(21,22)$. Bu nedenle hücre veya doku nakli olarak uygulanabilen paratiroit nakil verimliliğinin artırılması için kapsülasyon gibi alternatif yöntemlerin değerlendirilmesi önem kazanmıștır. 
Doğada bulunan polimerler; kolajen, kitosan, selüloz ve aljinattır (23). Bunlar arasında biyouyumluluğu ve FDA tarafından da birçok uygulama için onaylanmış polimer aljinattır. Aljinatın elde edileceği alg türüne bağlı olarak polimer özellikleri değişkenlik göstermektedir. Biyouyumluluğu en yüksek formu kahverengi algden elde edilen ultrasaf aljinat formudur (3). Son yillarda, paratiroit nakillerinde; sodyum aljinat, amitojenik aljinat, ultrasaf düşük yoğunluklu aljinat mikroenkapsülasyon için kullanılmıştır. Yapılan in vitro, in vivo ve klinik çalışmalar ümit vadetmektedir (3).

Paratiroit hücrelerinin mikroenkapsülasyonunda ekibimizin daha önce yaptı̆̆ 1 çalışmalar ile kapsülasyon sürecinde kullanılacak aljinat hazırlama yüzdesi, aljinatın çözücüsü ve belirlenen yüzdeye ait kullanılacak hücre sayısı gibi süreçler optimize edilmiştir (1). Bu çalışma özelinde ise ilk aşamada kapsülasyon öncesi hazırlanacak aljinat-hücre süspansiyonu arasındaki denge belirlenmiştir. Kullanılacak paratiroit hücre izolasyon metodu seçimi (mekanik veya enzimatik) ve bunun kapsül oluşumuna etkisi, devamında ise mikroenkapsülasyon oluşumu için kullanılacak optimum hacim/akış hızı dengesi de araştırılmıştır. Çalışmanın ilk aşamasında \%2'lik oranda hazırlanan farklı aljinat hacimleri ile sabit hücre-süspansiyon miktarına bağlı değişim takip edilmiştir. Oluşturulan kapsüllerin bir haftalık takibinde yalnızca \%28 oranında $(500 \mu \mathrm{L}$ aljinat:200 $\mu \mathrm{L}$ hücre-süspansiyonu hacmi) karıştırılarak hazırlanan kapsüller yapılarını in vitro ortamda korumuştur. Mekanik izolasyonla elde edilen paratiroit hücreleri morfolojik olarak mikro-doku parçalarına benzer özelliktedir. Buna bağlı olarak; \%28 karışım oranı korunarak, mekanik izolasyonla elde edilen paratiroit hücrelerinin iki ayrı akış hızında kapsülasyon verimliliği incelenmiştir. Düşük akış hızında heterojen boyut oluşumu gözlenmiş, cihazın itiş kapasitesi mikro-doku parçaları etkisiyle kapsül formasyonu oluşumunu engellemiştir. Akış hızını artırdığımızda ise oluşan mikroenkapsüllerin boyutları küçülse de tekil kapsül oluşumu mümkün olmamıştır. Kapsüllerin in vitro takibinde, PTH salınımlarının farklılığ kapsül morfolojilerine bağlı olarak hücrelerin beslenme-hormon salınım dengesinin bozulmasından kaynaklı olduğu düşünülmektedir. Enzimatik izolasyonla elde edilen paratiroit hücreleri ise kapsüle edilirken beş farklı akış hızı kullanılmış ve anlamlı morfolojik değişikliğin akış hızı arttıkça görüldüğü belirlenmiştir. 2,5mL/dk akış hızında kapsüller hem morfolojik açıdan eşit boyutlara ulaştığı hem de PTH salınımında sabit kültür koşullarında stabil olduğu istatistiksel olarak da ortaya konmuştur.

Aljinat-hücre süspansiyon oranının dengesi yapısal stabiliteyi desteklemektedir. Belirlenen bu oran korunarak uygulanan koşullarda ise enzimatik izolasyonun kapsül formasyonu oluşumunda daha etkili ve cihazın itiş kapasitesini bloke etmediği belirlenmiştir. Sonuç olarak elde edilen bulgular değerlendirildiğinde yüksek akış hızı, kapsül formasyonu oluşumunda verimliliği hem morfoloji hem de PTH salınım stabilitesi açından en iyi koşulları sağlamıştır. Gelecek çalışmalarda daha uzun süreli in vitro takiplerin değerlendirilmesi ve in vivo çalışmalar ile koşulların daha iyi hale getirilmesi hedeflenmektedir.

Hakem Değerlendirmesi: Dış bağımsız.

Peer Review: Externally peer-reviewed.

Bilgilendirilmiş Onam: Katılımcılardan bilgilendirilmiş onam alınmıştır.

Informed Consent: Written consent was obtained from the participants

Etik Komite Onayı: Bu çalışma için etik komite onayı Bezmialem Vakıf Üniversitesi Girişimsel Olmayan Araştırmalar Etik Kurulu’ndan alınmıştır (No: 54022451-050.05.04-522).

Ethics Committee Approval: This study was approved by the Bezmialem Vakif University Non-Invasive Research Ethics Committee (No: 54022451050.05.04-522).

Çalışma Konsepti/Tasarım- Ö.F.D., B.G.; Veri Toplama-Ö.F.D., B.G.; Veri Analizi/YorumlamaÖ.F.D., B.G., E.Y.; Yazı Taslağı- Ö.F.D., B.G.; İçeriğin Eleştirel İncelemesi-B.G., E.Y., Y.E.E.; Son OnayH.S.K., Y.E.E., A.A.

Author Contributions: Conseption- Ö.F.D., B.G.; Data Acquistion-Ö.F.D., B.G.; Data Analysis/Interpretation-Ö.F.D., B.G., E.Y.; Drafting Manuscript-Ö.F.D., B.G.; Critical Revision of Manuscript-B.G., E.Y., Y.E.E.; Final Approval-H.S.K., Y.E.E., A.A.

Çıkar Çatışması: Yazarlar çıkar çatışması beyan etmemişlerdir

Conflict of Interest: Authors declared no conflict of interest. 
Finansal Destek: Bu çalıșma Bezmialem Vakıf Üniversitesi Bilimsel Araştırma Projeleri Birimi tarafından desteklenmiştir (No: 20200204).

Financial Disclosure: This study was supported by Bezmialem Vakif University Scientific Research Projects Unit (No: 20200204).

\section{KAYNAKLAR}

1. Yucesan E, Basoglu H., Goncu B, Ozten Kandas N, Ersoy YE, Akbas F, Aysan E. In-vitro optimization of microencapsulated parathyroid cells. Dicle Medical Journal 2017;44(4):373-80.

2. Yücesan E, Göncü BS, Başoğlu H, Özten Kandaş N, Kanımdan E, Akbaş F, Ersoy YE. Aysan E, Experimental Alternative Method for the Treatment of Hypothyroidism: Capsulation of the Thyroid Tissue. Akdeniz Med J 2018;5(3):417-23.

3. Goncu B., Yucesan E. Microencapsulation for Clinical Applications and Transplantation by Using Different Alginates. 2021.

4. Fort A et al. Biohybrid devices and encapsulation technologies for engineering a bioartificial pancreas. Cell Transplant 2008;17(9):997-1003.

5. Jacobs-Tulleneers-Thevissen D et al. Sustained function of alginate-encapsulated human islet cell implants in the peritoneal cavity of mice leading to a pilot study in a type 1 diabetic patient. Diabetologia 2013;56(7):1605-14.

6. Basta $G$ et al, Long-term metabolic and immunological follow-up of nonimmunosuppressed patients with type 1 diabetes treated with microencapsulated islet allografts: four cases. Diabetes Care 2011;34(11): 2406-9.

7. Shin Eric Y et al. Adenosine Production by Biomaterial-Supported Mesenchymal Stromal Cells Reduces the Innate Inflammatory Response in Myocardial Ischemia/Reperfusion Injury. J Am Heart Assoc 2018;7(2): e006949.

8. Yucesan E et al. Microencapsulated parathyroid allotransplantation in the omental tissue. Artif Organs, 2019;43(10):1022-27.

9. Yucesan $\mathrm{E}$ et al. Fresh tissue parathyroid allotransplantation with short-term immunosuppression: 1-year follow-up. Clin Transplant 2017;31(11): doi:10.1111/ctr.13086.

10. Fukuda $S$ et al. The intraperitoneal space is more favorable than the subcutaneous one for transplanting alginate fiber containing iPSderived islet-like cells. Regen Ther 2019;1 1:65-72.

11. Omami $\mathrm{M}$ et al. Islet Microencapsulation:
Strategies and Clinical Status in Diabetes. Curr Diab Rep 2017;17(7):47.

12. Woodhams L, Al-Salami H. The roles of bile acids and applications of microencapsulation technology in treating Type 1 diabetes mellitus. Ther Deliv 2017;8(6):401-9.

13. Long $\mathrm{R}$ et al. Co-microencapsulation of BMSCs and mouse pancreatic $\beta$ cells for improving the efficacy of type I diabetes therapy. Int J Artif Organs 2017;40(4):169-175.

14. Cañibano-Hernández A et al. Alginate Microcapsules Incorporating Hyaluronic Acid Recreate Closer in Vivo Environment for Mesenchymal Stem Cells. Mol Pharm 2017;14(7):2390-9.

15. Hasse $\mathrm{C}$ et al, Amitogenic alginates: key to first clinical application of microencapsulation technology. World J Surg 1998;22(7):659-65.

16. Aysan E et al. Parathyroid Allotransplant With a New Technique: A Prospective Clinical Trial. Exp Clin Transplant 2016;14(4):431-5.

17. Aysan E et al. Parathyroid Allotransplant for Persistent Hypocalcaemia: A New Technique Involving Short-Term Culture. Exp Clin Transplant 2016;14(2):238-41.

18. Aysan E et al. Discharging a Patient Treated With Parathyroid Allotransplantation After Having Been Hospitalized for 3.5 Years With Permanent Hypoparathyroidism: A Case Report. Transplant Proc 2019;51(9):3186-8.

19. Brown WH. Parathyroid Implantation in the Treatment of Tetania Parathyreopriva. Ann Surg 1911;53(3):305-17.

20. Hasse $\mathrm{C}$ et al. First successful xenotransplantation of microencapsulated human parathyroid tissue in experimental hypoparathyroidism: longterm function without immunosuppression. J Microencapsul 1997;14(5):617-26.

21. Benvenuto LJ, Anderson MR, Arcasoy SM. New frontiers in immunosuppression. J Thorac Dis 2018;10(5):3141-55.

22. Barczynski MF. Golkowski, and I. Nawrot, Parathyroid transplantation in thyroid surgery. Gland Surg 2017;6(5):530-6.

23. Gasperini L, Mano JF, Reis RL. Natural polymers for the microencapsulation of cells. J R Soc Interface 2014;11(100):20140817. 